\title{
PENGANTAR BELAJAR STATISTIK DASAR
}

\author{
WAHYUNI RAMADANI
}

NIM: 18210009

Wahyuniuni1999@gmail.com

\begin{abstract}
ABSTRAK
Pengertian statistik yaitu kumpulan data yang memiliki bentuk berupa angka dan dapat disusun kedalam bentuk tabel maupun diagram. Yang mana isi tersebut dapat menjelaskan tentang masalah yang khusus. Statistik juga banyak digunakan pada sebuah penelitian dalam beberapa bidang, contohnya yaitu manufaktur, ekonomi, bisnis, pemasaran dan lain sebagainya. Dari statistik tersebut juga akan didapatkan sebuah kesimpulan yang akan memudahkan kita untuk mengambil keputusan.
\end{abstract}

Kata kunci : statistik, statistika , data , diagram , penelitian 


\section{BAB I}

\section{PENDAHULUAN}

\section{A. Latar belakang}

Statistik berasal dari kata state yang artinya Negara. Dalam pengertian yang paling sederhana statistic artinya data. Dalam pengartian yang lebih luas, statistic dapat di artikan sebagai kumpulan data dalam bentuk angka maupun bukan angka yang disusun dalam bentuk tabel ( daftar ) dan atau diagram yang menggambarkan ( berkaitan ) dengan suatu masalah tertentu.

Data merupakan bahan baku informasi, dapat di definisikan sebagai kelompok teratur simbol - simbol yang mewakili kuantitas, fakta, tindakan, benda dan sebagainya.

Populasi ialah kumpulan dari organisme jenis yang dapat berdiak silang sedangkan komunitas atau bisa juga di artikan sebagai kumpulan dari beberapa populasi yang hidup disuatu areal tertentu.

Sampel adalah sebagian dari jumlah dan karakteristik yang dimiliki oleh populasi tersebut.

\section{B. Tujuan penulisan}

Makalah ini akan membahas beberapa pokok materi statistic,diantaranya sebagai berikut :

1. Apakah pengertian statistik ?

2. Apakah pengertian data ?

3. Apakah pengertian populasi ?

4. Apakah pengertian sampel ? 


\section{BAB II \\ PEMBAHASAN}

\section{A. Pengertian statistik, data, sampel, dan populasi menurut dua pendapat}

\section{Statistik}

Secara umum, statistik merupakan disiplin ilmu yang mempelajari metode dan prosedur pengumpulan, penyajian, analisa, dan penyimpulkan suatu data mentah, agar menghasilkan informasi yang lebih jelas untuk keperluan suatu pendekatan ilmiah dan dapat dikelompokkan menjadi dua bagian yaitu statistik deskriptif dan statistik inferensial berikut ini adalah pengertian dan definisi statistik :

a. Anderson and Barcrof

Statistik adalah ilmu dan seni pengembangan dan penerapa metode yang paling efektif untuk kemungkinan salah dalam kesimpulan dan estimasi dapat diperkirakan dengan menggunakan penalaran induktif bersarkan matematika probalitas.

\section{b. UU RI No. 7 Tahun 1960}

Statistik adalah keterangan berupa angka angka yang memberikan gambaran yang wajar dari seluruh ciri - ciri kegiatan dan keadaan masyarakat Indonesia.

\section{c. Sujana}

Statistik adalah pengetahuan yang berhubungan dengan cara cara pengumpulan fakta, pengolahan serta penganalisanya, penarikan kesimpulan serta pembuatan keputusan serta pembuatan keputusan yang cukup beralasan berdasarkan fakta dan penganalisa yang dilakukan.

2. Pengertian data

a. Wahyu suprianto dan Ahmad Muhsin

Data merupakan bahan baku informasi, dapat di definisikan sebagai kelompok teratur simbol simbol yang mewakili kuantitas, fakta, tindakan, benda, dan sebagainya.

b. Zulkiffi A.M

Data adalah keterangan atau bukti mengenai suatu kenyataan yang masih mentah, masih berdiri sendiri - sendiri, belum di organisasikan dan belum di olah. 
c . Kuswadi dan E.Mutiara

Data adalah kumpulan informasi yang diperoleh dari suatu pengamatan, data berupa angka, lambing atau sifat.

3. Pengertian populasi

a. Dr. Ir. Adji Sastrosupadl, MS

Populasi adalah keseluruhan bahan atau data yang kita teliti, misalnya tinggi badan mahasiswa

b. Chairani Hanum

Populasi ialah kumpulan dari organisme - organisme sejenis yang dapat berbiaksilang sedangkan komunitas atau bisa juga di artikan sebagai kumpulan dari beberapa populasi yang hidup disuatu area tertentu.

4. Sampel

a. Menurut Sugiyono

Sampel adalah sebagian dari jumlah dan karakteristik yang dimiliki oleh populasi tersebut.

b. Menurut Arikunto

Sampel adalah sebagian atau wakil populasi yang teliti. 


\section{BAB III}

\section{PENUTUP}

\section{A. Kesimpulan}

Dari semua materi di atas dapat disimpulkan bahwa statistik, data, populasi dan sampel merupakan yang sangat dibutuhkan dalam membuat sebuah penelitian. Karena tanpa ada ke empat hal tersebut diatas maka sebuah penelitian akan sulit untuk di atur datanya. Karena data yang kita teliti dalam bentuk populasi sangat banyak. Dengan adanya empat hal tersebut maka penelitian dapat dilakukan dengan mudah karena ada teknik - teknik yang memudahkan berjalannya sebuah penelitian.

\section{B. Saran}

Makalah ini masih sangat jauh dari kesempurnaan, baik dari segi penyajian bahan maupun dalam segi penulisan. Oleh sebab itu, penulis sangat mengharapkan kritik dan saran pembaca agar karya tulis ini bisa menjadi berguna bagi pendidikan di Indonesia. 


\section{DAFTAR PUSTAKA}

Arsyam, M (2020). Manajemen pendidikan islam.

Heriyanto, H. (2020) Teknik menulis artikel konseptual.

Heriyanto,H. (2020) telah kurikulum 2013 : hasil Revisi tahun2018.

Jusmiana, A., dan Heriyanto, H. (2020). Suplemen materi statistik terapan dalam ilmu kesehatan.

Sappada, A. O., dan Arsyam, M(2020) Ilmu pengetahuan dan teknologi menurut pandangan islam.

Tidak ada daftar pustaka yang tertera di media yang saya dapatkan. 